\title{
Properties of pre-cast terrazzo tiles and recommended specifications
}

\author{
(Propriedades de telhas de terrazzo pré-moldadas e \\ especificações recomendadas)
}

\author{
G. Karam, M. Tabbara \\ Associate Professors of Civil Engineering, Lebanese American University, P.O. Box 166864, Beirut, Lebanon \\ gkaram@lau.edu.lb,mtabbara@lau.edu.lb
}

\begin{abstract}
A targeted experimental program was carried out to establish basic reference physical and mechanical properties of commercially available pre-cast marble chip terrazzo tiles and to investigate the effects of varying manufacturing process parameters on those properties. The transverse strength, density, water absorption, and abrasion resistance were measured as a function of casting pressure and residence time in the casting mold for a standard mix design. A simple surface abrasion index test was developed and applied comparing pre-cast terrazzo tiles with reference natural tiling stones. Recommendations for improving existing specifications and developing quality control measures are presented.
\end{abstract}

Keywords: terrazzo, materials technology, quality control, strength and testing of materials.

\section{Resumo}

Foi feito um programa experimental direcionado para estabelecer propriedades físicas e mecânicas como referências básicas de telhas de terrazzo de peças de mármore pré-moldadas disponíveis comercialmente e para investigar os efeitos de vários parâmetros de processo de fabricação nessas propriedades. A resistência transversal, a densidade, a absorção de água e a resistência ao desgaste foram medidas em função da pressão de moldagem e do tempo de residência do molde de um projeto de mistura padrão. Um teste simples de índice de desgaste de superfície foi desenvolvido e aplicado na comparação de telhas de terrazzo pré-moldadas com pedras de telhas naturais de referência. As recomendações para a melhoria das especificações existentes e o desenvolvimento de medidas para controle de qualidade são apresentadas.

Palavras-chave: terrazzo, tecnologia de materiais, controle de qualidade, resistência e teste de materiais.

\section{INTRODUCTION}

Terrazzo is a word derived from the Italian to designate any mosaic flooring made by embedding small pieces of marble or colored stone in mortar followed by polishing the surface. The National Terrazzo and Mosaic Association (NTMA) [1] definition reads: "Terrazzo consists of marble, granite, onyx or glass chips in Portland cement or resinous matrix. The terrazzo is poured, cured, ground and polished. Typically used as a finish for floors, stairs or walls. Terrazzo can be poured in place or pre-cast". Standard LS38:1966 of the Lebanese Standards Institution [2] specifies pre-cast terrazzo tiles as "composed of two bonded layers, the upper one having a smooth surface and constituted of cement, usually white cement, mixed with predetermined amounts of marble chips or other hard stone, and of powdered stone or marble. The lower layer shall be constituted of ordinary Portland cement, sand, and aggregate mostly between $0.1 \mathrm{~mm}$ and $2.0 \mathrm{~mm}$ in size" (Fig. 1).

Pre-cast terrazzo tiles are widely used as floorings in the Mediterranean countries, the Middle East, and parts of America and Asia, in residential, commercial, and institutional buildings. Tiles are manufactured in square

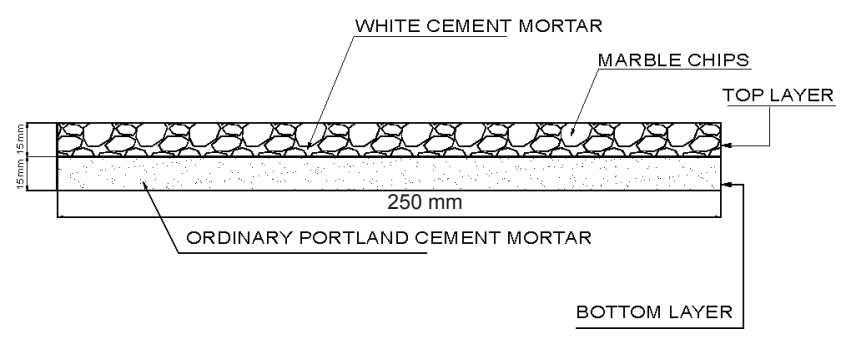

Figure 1: Pre-cast terrazzo tile cross-section.

[Figura 1: Secção de uma telha de terrazzo pré-moldada.]

sizes varying typically from $10 \mathrm{~cm}$ x $10 \mathrm{~cm}$ up to $40 \mathrm{~cm}$ x $40 \mathrm{~cm}$, mechanically vibrated in the mold, hydraulically pressed, water or air cured, then grit polished before being shipped to site. Final polish is performed in situ after setting and leveling the pre-cast tiles on a sand bed.

Rigid stainless steel molds used in the manufacture of the tiles are filled manually or automatically with the marble chips then sufficient amounts of white cement grout are poured to fully enclose the marble chips followed by a backing layer of Portland cement mortar in measured quantities. The molds are then vibrated and the mix is hydraulically pressed to the required pressure for a few seconds before being released. 
The tile is then de-molded and stored for curing. Automatic or manually operated equipment can be used. The large variations in the quality of the pre-cast terrazzo tile available on the Middle Eastern market are mainly due to the lack of clear and well designed specifications as well as the absence of strict quality control procedures in manufacturing. The purpose of the work presented in the rest of this paper is three fold: first to establish a reference baseline for the physical and mechanical properties of the pre-cast terrazzo tiles available in the market; second, to investigate the effect of varying the casting pressure and the number of passes in the hydraulic press on the properties of those tiles in order to optimize the manufacturing process and establish quality control procedures [3]; and third to recommend effective and feasible modifications and improvements to construction specifications currently being used.

\section{MATERIALS AND TESTING METHODS}

Reference information and general guidelines about terrazzo tiles are provided by national trade associations where available such as the National Terrazzo and Mosaic Association (NTMA) [1] in the USA, the National Federation of Terrazzo Marble and Mosaic Specialists (NFTMMS) [4] in the UK, and the Terrazzo Tile and Marble Association of Canada (TTMAC) [5]. Manufacturing and testing details as well as specifications are in most cases left to the standardization institutions and the construction specifications agencies.

The Lebanese Standards Institution [2] covers the subject in standard LS38:1966. The British Standards Institution covered the topic in standard BS 4131:1973 which was replaced since 2004 by BS EN 13748-1 and BS EN 13748-2 [6]. It is worthy to note that the American Society for Testing and Materials (ASTM) has no specification for pre-cast terrazzo tiles.

Square terrazzo tiles, $25 \times 25 \times 3 \mathrm{~cm}^{3}$, where manufactured at a local Lebanese factory according to the general specifications of LS38:1966 consisting of two layers: a 1.5 $\mathrm{cm}$ thick white hydraulic cement layer enclosing Carrara marble chips and $1.5 \mathrm{~cm}$ thick regular gray hydraulic cement mortar backing. Grain size distribution of the marble chips, marble powder filler, and aggregates for the mortar backing were all selected according to LS38:1966 [2] and NTMA [1] recommendations. The standard pressure of $9.8 \mathrm{MPa}$ (100 bar) was maintained and the number of passes in the hydraulic press was varied from one to four passes with a fixed pressing time of $5 \mathrm{~s}$ per pass. Table I summarizes the testing program, showing the different tiles manufactured as well as their testing results.

The following properties were measured for each tile as per BS 4131:1973 [6]: transverse strength in three point bending, surface water absorption, total water absorption, and density. Surface water absorption was measured after

Table I - Testing program and results.

[Tabela I - Programa de testes e resultados.]

\begin{tabular}{ccccccc}
\hline Tile Nr. & $\begin{array}{c}\text { Number of } \\
\text { passes in press } \\
\text { at } 9.8 \mathrm{MPa}\end{array}$ & $\begin{array}{c}\text { Density } \\
\left(\mathrm{g} / \mathrm{cm}^{3}\right)\end{array}$ & $\begin{array}{c}\text { Water absorption } \\
\text { by face }\left(\mathrm{g} / \mathrm{mm}^{2}\right)\end{array}$ & $\begin{array}{c}\text { Total water } \\
\text { absorption }(\%)\end{array}$ & $\begin{array}{c}\text { Transverse } \\
\text { strength } \\
(\mathrm{MPa})\end{array}$ & $\begin{array}{c}\text { Abrasion weight } \\
\text { loss }(\mathrm{g})\end{array}$ \\
\hline 1 & 1 & 2.07 & 0.42 & 6.49 & 4.05 & 6.5 \\
2 & 1 & 2.08 & 0.43 & 6.51 & 5.16 & 6.8 \\
3 & 1 & 2.07 & 0.42 & 6.33 & 5.04 & 6.9 \\
4 & 2 & 2.14 & 0.39 & 6.35 & 3.90 & 6.8 \\
5 & 2 & 2.14 & 0.39 & 5.99 & 5.30 & 6.9 \\
6 & 2 & 2.17 & 0.39 & 6.54 & 5.20 & 8.7 \\
7 & 3 & 2.14 & 0.41 & 5.99 & 4.67 & 7.2 \\
8 & 3 & 2.11 & 0.41 & 6.16 & 5.23 & 7.1 \\
9 & 3 & 2.10 & 0.40 & 6.41 & 4.56 & 6.1 \\
10 & 4 & 2.11 & 0.41 & 5.83 & 3.91 & 7.2 \\
11 & 4 & 2.11 & 0.40 & 6.05 & 4.78 & 6.9 \\
12 & 4 & 2.10 & 0.40 & 6.17 & 4.26 & 6.0 \\
$13^{\mathrm{a}}$ & 2 & 2.11 & 0.43 & 6.23 & 4.22 & 6.8 \\
$14^{\mathrm{a}}$ & 2 & 2.10 & 0.43 & 6.20 & 4.44 & 7.4 \\
$15^{\mathrm{a}}$ & 2 & 2.12 & 0.36 & 6.27 & 4.55 & 7.2 \\
$16^{\mathrm{b}}$ & 2 & 2.03 & 0.45 & 8.16 & 3.95 & \\
$17^{\mathrm{c}}$ & 2 & & & 6.86 & 6.19 & \\
$18^{\mathrm{c}}$ & 2 & & & 7.73 & 5.63 & \\
\hline
\end{tabular}

${ }^{a}$ Casting pressure doubled to $20 \mathrm{MPa} ;{ }^{b}$ all white cement mortar tile; ${ }^{c}$ all ordinary Portland cement mortar tile. 
soaking the tiles face down in $5 \mathrm{~mm}$ of water for $24 \mathrm{~h}$, whereas total water absorption was measured after soaking the whole tile in water for $24 \mathrm{~h}$.

A new and simpler index abrasion test was developed along the general principle of ASTM C944-99 [7] to replace the cumbersome set up recommended in LS38:1966 [2]. The new method was used to measure the surface abrasion resistance of the different terrazzo tiles, and to establish a comparison with typical natural stone flooring tiles. The testing apparatus consisted of fitting a standard drill press with a $2 \mathrm{~cm}$ diameter stone polishing head. The head was then brought in contact with the finished tile surface at a speed of $1250 \mathrm{rpm}$ with an application force of $19.6 \mathrm{~N} \mathrm{(2}$ $\mathrm{kg}$ ). The application time was adjusted to $30 \mathrm{~s}$, enough to cause a measurable weight loss due to abrasion. The same application time was used on all tiling materials. This surface abrasion test can be used to index and compare the properties of tiling materials when subjected to a standard abrasive effort.

\section{RESULTS AND DISCUSSION}

The results of the testing program are presented in Table I and Fig. 2 for density, total water absorption, face water absorption, and transverse strength versus number of passes in the press at 9.8 MPa and 19.6 MPa.

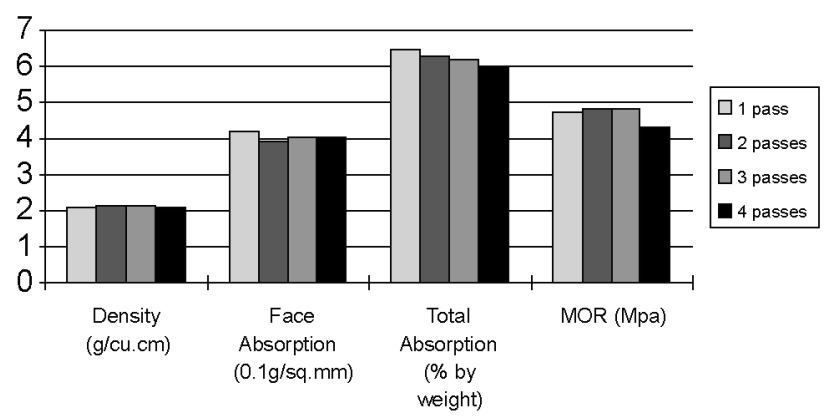

Figure 2: Variation of pre-cast terrazzo tile properties with number of pressing passes.

[Figure 2: Variação das propriedades de telhas de terrazzo premoldadas com o número de passos de prensagem.]

Fig. 2 compares the average results of the three specimens at the same number of passes in the press. All specimens tested had a modulus of rupture (or transverse strength) in excess of the $3 \mathrm{MPa}$ required by BS-4131 [6]. The density and the transverse strength increase at constant casting pressure with the number of passes showing a small peak between two to three passes then decrease at four passes. This is probably due to an initial reduction in air voids and a higher compaction. An increase in casting pressure application seems to result in loss of water, and may also result in some of the observed fracturing of the marble chips. That would explain the optimal point observed. The face water absorption follows the same interpretation showing an initial decrease with a minimum due to the higher density and face sealing around two passes followed by an increase which may be also attributed to the observed cracking of the marble chips. It is believed that higher pressing times allow more transfer of casting pressure from the liquid mortar to the solid marble chips, albeit under a transient internal pressure regime. The total water absorption measured by immersion in water shows a steady decrease with increased casting pressure. That is because the dominant effect is the absorption capacity of the mortar backing which is reduced systematically with higher pressing time and compaction. For comparison purposes, a set of three tiles was manufactured using double the casting pressure, i.e. almost $19.6 \mathrm{MPa}$, and two passes. The results are presented in Table 1, showing properties similar to the specimens subjected to four passes at regular casting pressure. Fracturing of the marble chips was also observed. Abrasion resistance, or weight of removed material under a standard abrasive effort, is presented in Table I for all specimens. Results show very little variation with casting pressure because the surface abrasion properties are independent of casting pressure or time.

Table II compares the abrasion resistance of pre-cast terrazzo tiles with other natural stone flooring materials, including black granite the hardest in use, commercially known as "Nerro Absoluto". As expected the abrasion resistance of the terrazzo tile surface falls between that of Carrara marble and white cement mortar the two components of the tile face. Surface measurements show that the marble chips cover around 50 to $60 \%$ of the total polished tile surface, the rest being filled by white cement. Using a rule of mixtures with these proportions the surface abrasion weight loss of the tile can be predicted to fall between $5.08 \mathrm{~g}$ and $6.05 \mathrm{~g}$ close to the measured $6.7 \mathrm{~g}$ weight loss.

Once installed in place, the long term durability of precast terrazzo tiles is mostly affected by the surface abrasion resistance and the surface water absorption characteristics. Transverse strength would become important in the case of discontinuous backing and loss of proper support. Even the

Table II - Comparative abrasion test results. [Tabela II - Resultados comparativos de testes de desgaste.]

\begin{tabular}{cc}
\hline Type of Surface & $\begin{array}{c}\text { Abrasion } \\
\text { Weight Loss (g) } \\
\text { (average of } \\
\text { three tests) }\end{array}$ \\
\hline Pre-cast Terrazo Tile & 6.7 \\
Ordinary Portland Cement Mortar & 6.4 \\
White Cement Mortar & 10.9 \\
Carrara Marble & 1.2 \\
Rose Aurore Granite & 0.8 \\
Himalayan Blue Granite & 0.4 \\
Statuario Granite & 0.3 \\
Nerro Absoluto Granite & 0.1 \\
\hline
\end{tabular}


smallest improvements in these mechanical properties may result in notable improvements in durability. However this improvement needs to be weighed against the increase in production cost. The cycle time of automated high output carrousel presses averages between 11 to 13 seconds. Doubling the pressing time for optimal mechanical properties will result in around $50 \%$ increase in cycle time, which would cause close to $30 \%$ decrease in total output. Manually operated presses such as those used in the manufacture of the tiles for the experimental program would also suffer a decrease in output if the pressing time is doubled. Market value added of durability would determine if the change in manufacturing process is economically warranted.

\section{RECOMMENDATIONS FOR SPECIFICATIONS}

LS38:1966 [2] prescribes manufacturing and testing methods without required minimum properties following the approach of most trade associations. The burden of specifying the minimum physical and mechanical properties are left for the construction manager developing of the specification. The baseline properties established for the "top quality" marble chip pre-cast terrazzo tiles available in the Lebanese and Middle Eastern market have showed that those tiles exceed BSI-4131 minimum strength requirement by $30 \%$.

A survey of typical specifications for terrazzo tiles has shown a mix of prescriptive and descriptive approaches with widely varying physical and mechanical requirements. Some of these are manufacturer developed [8], some are user developed [9]. Some of the specifications encountered by the authors went all the way to specify not only the composition of the tile mortar but the casting pressure as well. The results of the testing program showed that the manufacturing process was already close to optimal and that no major improvements could be achieved by specifying any minimum casting pressure or residency time in the mold. Based on the review above and the results of the experimental program it is recommended that specifications be as descriptive as possible concentrating on key performance and durability measures such as transverse strength, surface abrasion, surface water absorption, and marble chip surface coverage, leaving all process and mix design prescriptions at the responsibility of the manufacturer. The baseline data presented in this paper for the different material properties can serve to specify those descriptive measures.

\section{CONCLUSIONS}

Baseline properties were established for so-called "top quality" marble chip terrazzo tiles to allow for descriptive specifications development.

A simple surface abrasion test procedure was proposed and comparative measures established with reference natural tiling stones.
The current manufacturing process for pre-cast terrazzo tiles is very close to optimal in terms of the casting pressure and press time being used. Improvements of the order of 3 to $6 \%$ could be achieved in the measured mechanical properties by varying the process variables considered.

Higher casting pressure or additional pressing time resulted in fracturing of the marble chips and a net reduction in relevant tile properties.

Marginal improvements in mechanical properties could be achieved up to the resistance limits of the marble chips and the added cost of production.

\section{ACKNOWLEDGEMENTS}

The experimental work was carried out as part of the final year project of Eng. Wissam A. Abi-Nahed under the supervision of the first author at the laboratories of the Institute for Geotechnics and Materials (IGM s.a.rl.).

\section{REFERENCES}

[1] National Terrazzo and Mosaic Association, Terrazzo Ideas and Design Guide (1994), The National Terrazzo and Mosaic Association Inc., 3166 Des Plaines Avenue, Suite 121, Des Plaines, Illinois, 60018, USA, http://www.ntma. com.

[2] LIBNOR, LS38 Terrazzo Tiles, Lebanese Standards Institution (1966), Getco Ctr., Sin El Fil, Lebanon, http:// www.libnor.org.

[3] C. Rathke, High-Value Paver Technology Arrives, Concrete Products (January ${ }^{\text {st }}$, 2000).

[4] National Federation of Terrazzo, Marble \& Mosaic Specialists, Specifications (2005), PO Box 2843, London, W1A 5PG, UK, http://www.nftmms.org.

[5] Terrazzo Tile \& Marble Association of Canada, Technical Information, TTMAC Toronto, 163 Buttermill Avenue, Unit 8, Concord, Ontario L4K 3X8, Canada, http://www.ttmac. com.

[6] British Standardas Institute, Specification for Terrazzo Tiles BS 4131 (1973), Terrazzo Tiles for Internal Use BS EN 13748-1 and Terrazzo Tiles for External Use BS EN 137482, BSI, 2 Park Street, London W1A 2BS, http://www.bsiglobal.com.

[7] American Society for Testing and Materials, Standard Test Method for Abrasion Resistance of Concrete or Mortar Surfaces by the Rotating - Cutter Method, ASTM C944-99 (2005), ASTM International, 100 Barr Harbor Drive, PO Box C700, West Conshohocken, PA, 19428-2959 USA, http://www.astm.org.

[8] Rover North America Guide Specification, Section 090300, Precast Terrazzo Tile, 2002, Rover North America, Erlanger, Kentucky 41018, USA.

[9] Unified Facilities Guide Specifications, Section 096616, Terrazzo Tile, 2006, US Army Corps of Engineers, http:// www.usace.army.mil.

(Rec. 16/04/2008, Ac. 26/06/2008) 